\title{
Correlation of Reading Interests and Learning Motivation Toward Science Learning Outcomes
}

\author{
${ }^{*}$ Luh Tu Selpi Wahyuni1, I Gusti Ngurah Japa ${ }^{2}$, Ni Wayan Rati ${ }^{3}$ \\ 1,2,3 Program Studi Pendidikan Guru Sekolah Dasar, Universitas Pendidikan Ganesha, Singaraja, Indonesia
}

\section{A R T I C L E I N F O \\ Article history: \\ 1 Mei 2020 Received in revised form \\ 11 Juni 2020 \\ Accepted 10 Juli 2020 \\ Available online 25 Agustus 2020}

Kata Kunci:

Minat membaca, motivasi,

IPA

Keywords:

Interest in reading,

motivation, science

\begin{abstract}
A B S T R A K
Rendahnya minat membaca dan motivasi belajar dikarenakan kurangnya dukungan keluarga, sekolah dan masyarakat untuk meningkatkan minat membaca serta motivasi belajar siswa. Penelitian ini bertujuan untuk mengetahui hubungan minat membaca dan motivasi belajar dengan hasil belajar IPA kelas V SD. Jenis penelitian ini adalah penelitian ex post facto. Populasi penelitian ini sebanyak 187 orang. Sampel ditentukan menggunakan teknik random sampling dan terpilih sebanyak 144 orang. Data yang dikumpulkan adalah minat membaca dan motivasi belajar siswa menggunakan instrumen kuesioner serta pencatatan dokumen. Data dianalisis dengan analisis regresi sederhana, korelasi product moment dan analisis regresi ganda. Hasil penelitian yang didapat pertama, nilai $r$ hitung $0.832>r$ tabel 0.138 yang artinya terdapat hubungan yang signifikan minat membaca dan
\end{abstract} hasil belajar IPA. Kedua, nilai $r$ hitung $0.988>r$ tabel 0.138 yang artinya terdapat hubungan yang signifikan motivasi belajar dan hasil belajar IPA. Ketiga, nilai $r$ hitung $0.988>r$ tabel 0.164 yang artinya terdapat hubungan yang signifikan minat membaca dan motivasi belajar dengan hasil belajar IPA. Hubungan tersebut menunjukkan jika minat membaca dan motivasi belajar siswa tinggi hasil belajar siswa cenderung tinggi. Hal itu berarti minat membaca dan motivasi belajar siswa sangat penting ditanamkan dalam proses pembelajaran guna mempertahankan hasil belajarnya yang baik dan meningkatkan hasil belajar siswa.

\section{A B S T R A C T}

The low reading interests and learning motivation are the main problems in this study. That is due to the lack and support of families, schools, and communities to increase reading interests and learning motivation. This study aimed to determine the relationship of reading interests and learning motivation with the learning outcomes of science class $\mathrm{V}$ of primary school (elementary school). This type of research was ex-post facto research. The population of this study was 187 people. The sample was determined using random sampling techniques and 144 people were selected. The data collected was an interest in reading and student motivation to use questionnaire instruments and document recording. Data were analyzed by simple regression analysis, product-moment correlation, and multiple regression analysis. The results of the study obtained first, the value of $r$ count $0.832>r$ table 0.138 which means that there is a significant relationship between reading interests and science learning outcomes. Second, the value of $r$ count $0.988>r$ table 0.138 which means there is a significant relationship between learning motivation and science learning outcomes. Third, the value of $r$ count $0.988>r$ table 0.164 which means that there is a significant relationship between reading interests and learning motivation with the results of learning science. The relationship shows that if students' reading interests and learning motivation is high, student learning outcomes tend to be high. It means that students' reading interests and learning motivation are very important to be instilled in the learning process to maintain good learning outcomes and improve student learning outcomes. 


\section{Introduction}

Science study learning focuses the students at direct learning experience thus the students can develop varied knowledge related to how scientific work and a deep understanding of the concept of nature and its surroundings, whether it comes from literature or direct nature, the student needs to be assisted in during the learning process (Sahrudin, 2013). (Lawe, 2018) states that science study emphasizes on the deeper knowledge so the students can understand the surrounded environment supported by facts on the field. This ability will be realized if science education is successful in fostering the ability to think logically, critically, creatively, and to take the initiative in change and development. (Widani et al., 2019) argue that the scientific study learning process on the primary school must be able to equip students with a set of competencies and skills and values needed by them to know themselves, the environment, and the future challenges they will face. For students to be able to understand conceptually about science learning, a strong interest in reading is needed. Students need more reading intensity to understand the concepts in science material, with students' reading interest it is easy to find information on concepts contained in science reading books with student reading activities able to improve learning outcomes.

One of the factors which can improve the students' learning outcomes is interest in reading is high, making it easier for students to obtain information. Reading activities are one of the abilities needed in human life to obtain various unknown information (Safitri \& Muslim, 2019). (Yuzal, 2017) states that reading interest is a strong willingness equipped by efforts to read. Someone who has a strong reading interest is reflected in his willingness and effort in seeking the reading material and then read it under his consciousness. Interest can be said as a tendency towards something. The tendency of students to read is largely influenced by internal and external factors. This was confirmed by (Triatma, 2016) that two factors influence students' reading interest; internal and external factors. Internal factors are feeling, attention, and motivation. Meanwhile, the external factors include lecturers' role, environment, and facilities. Thus, without the fulfillment of these factors, students' reading interest will not be able to develop properly. The benefits of reading in everyday life according to Taufina (Mumpuni, 2019) namely: 1) insight opening; 2) new thinking; 3) increase intelligence in all fields; and 4) increasing independence in seeking knowledge. Therefore, interest in reading must be cultivated as early as possible.

But in fact, based on UNESCO data (2016) the percentage of reading interest in Indonesians is 0.001 percent. This means that out of 1,000 Indonesians, only 1 person is an avid reader. Indonesia experienced a cultural leap from a speech culture to a viewing culture, without going through a reading culture first (Triatma, 2016). Republika (Permatasari, 2015) states that the average amount of time Indonesian children watch TV is 300 minutes per day. This number is much greater than children in Australia which only 150 minutes per day, in America only 100 minutes per day, and in Canada only 60 minutes per day. This statement implies that Indonesian children themselves prefer to watch TV than reading (Triatma, 2016). The low reading interest of Indonesian children is also accompanied by a low reading interest in Indonesian society. The reading interest of the Indonesian people, especially children is relatively low, this is because they prefer to go to entertainment venues (internet cafes, malls, play stations, and others) than to libraries. (Shofaussamawati, 2014) supports the statement, The UN revealed that from one newspaper given to children in Indonesia, only 25 people read it. Ideally, what the UN tolerates is 10 people for one newspaper. As for books, there are 35 titles for one million people Galus (Triatma, 2016).

The same thing happened in a school in Singaraja. Based on the observations made, in learning activities most students spend time off to the canteen and play with their friends compared to the library to read books. According to (Fitriyani, 2018), she says that several factors can stimulate the rise of interest in visiting the community, these factors are: 1) High curiosity about the place and condition you want to visit; 2) Attractive environmental conditions and adequate facilities; 3) The condition of a friendly social environment is also conducive. This means that safety and comfort must be prioritized; 4) Availability of the desired needs; 5) Principled that visiting the library is a lifestyle. In addition, there are also internal and external factors that influence student visits to the library. Internal factors from within students include a tendency to be lazy in their activities, students have other activities such as extracurricular activities and organizations so that they do not have time to read in the library and laziness can be caused by low interest and motivation in students. In addition, there are also external factors that affect the students' lack of interest in reading, namely the books available in the library are less varied so that students are less interested in going to the library. The low reading interest of students can be determined by various factors. From inside the student and from outside the student. Factors that come from within students include physiological conditions and psychological conditions. Physiological conditions in general greatly affect a person's learning ability and of course reading is no exception. Factors originating from outside the student can take the form of the natural environment, learning facilities and facilities, 
teaching methods, media, materials, and the teacher himself. Along with that, it must also get the attention of students so that it gives the impression that writing lessons are also boring (Putri, 2011).

After the reading interest, learning motivation is also important in the process of science learning. Science study is one of the subjects that give experience and important roles for the students. (Alannasir, 2016) states that Learning motivation is very important for student success to obtain optimal learning outcomes. Learning motivation is an indicator of the success of a learning process, many factors influence learning motivation, including internal factors and external factors. One of the supporting factors that can affect learning motivation is by utilizing or using learning media. (Uno, 2008:3) argues that Motivation is a power that can motivate students to want to learn, ensure continuity of learning activities, direct students to focus on learning so that students can achieve optimal results in learning. The teacher has to arouse student motivation so that students want to carry out a series of learning activities. Student motivation to learn can arise from within the individual (intrinsic motivation) and can arise from outside the student (extrinsic motivation). Extrinsic motivations are active motives that function if there is an external stimulus. Motivation from outside students related to science lessons, namely carrying out activities that are influenced by parents, friends, people around them, as well as assignments given by the teacher. Meanwhile, when it is related to natural science learning in elementary schools, students' intrinsic motivation can result in students being interested in learning and doing anything related to natural knowledge based on their desires and wishes. This motivation is a type of motivation that arises from within students.

Motivation is a conscious effort to move, direct, and maintain a person's behavior so that he is motivated to act to do something to achieve certain results or goals (Ghullam, 2011). Motivation will arise from students if they are more relevant to the assignment given to students' personal goals, then students will be more enthusiastic and motivated to do so. An example is that students are given assignments by the teacher to look for objects that can conduct heat and objects that cannot conduct heat, this task can motivate students because by looking for these objects students can choose the right objects to use in daily activities. The existence of high motivation is used to move students to learn not only as a requirement, but also a necessity for them. Motivation has an important role in student learning activi ties, as stated in the following statement "motivation has an important role in learning and learning, among others in (a) determining things that can be used as learning reinforcement, (b) clarifying the learning objectives to be achieved, ( c) determine the variety of controls on learning stimuli, (d) determine learning persistence (Uno, 2008:27).

However, the fact that what happens in the field shows that many science learning is taught with methods that are not in accordance with the characteristics of science learning (Laksana, 2017). In the learning process, students are less encouraged to develop their thinking skills. The learning process in the classroom is mostly directed at the student's ability to memorize information, the child's brain is forced to remember and accumulate information without being required to relate it to everyday life. Such a learning process will make students get bored quickly in participating in in-class learning (Benge, 2017). They often do not pay attention to lessons, even they sometimes play or talk with friends when the learning process is in progress so that the class becomes noisy and the lessons conveyed by the teacher become ineffective. Ahl is also caused because students are not actively involved in learning activities so that students do not do meaningful learning.

This also happened in one elementary school in Singaraja. Based on the results of observations, students' motivation in participating in science learning was lacking because at the time the science learning activities were still focused on the material presented by the teacher which caused students to be less enthusiastic in science learning activities. The teacher never invites students to learn based on direct observation of the environment related to the science material being studied. On the other hand, by inviting students to directly dive into the environment for observation, it will make students feel happier. Besides, some students do not respond to what is said during learning activities, and some students forget to do their homework. Learning is also still centered on the teacher. Teachers are more active in in-class activities, so this is a scourge that makes students feel bored, less enthusiastic, and less motivated to take part in learning. If this is done continuously, it will affect the achievement of student learning outcomes. The result of low reading interest and low student motivation is shown from the results of recording documents that show that out of 187 students only 48 students scored above the KKM (a passing grade), and the remaining 139 students got science learning outcomes below the KKM.

From the description and learning outcome data, it is seen that if the students' interest in reading and learning motivation is lacking, this will affect the student's science learning outcomes. This is reinforced by the results of research conducted by previous research which states that student learning achievement is the result of learning which is a description of the success of student abilities (Novauli, 2015). Besides, based on (Pratama, 2019) Science learning outcomes are also strongly influenced by 
motivation from within students. Previous research was also carried out by (Oktarilla, 2019) about the contribution of reading interest and learning motivation to the writing skills of seventh-grade students of SMP Negeri 7 Padang. In his research, he found that first, there was a contribution of reading interest to the writing skills of seventh-grade students of SMP Negeri 7 Padang by $26.13 \%$. Second, there is a contribution of learning motivation to the writing skills of the seventh-grade students of SMP Negeri 7 Padang of $3.2 \%$. Third, there is a contribution of reading interest and learning motivation to the writing skills of seventh-grade students of SMP Negeri 7 Padang by $30.25 \%$. Thus, it can be seen that the higher the reading interest and student motivation, the higher the skill level of writing descriptive texts of the students. other than that, (Maola, 2019) also conducted a similar study on the relationship between reading interest and learning achievement of Indonesian Language competence in grade IV SD students. He found that there was a significant relationship in reading interest in the fourth-grade Indonesian competency learning achievement at SD Negeri Kalisari 3 Demak. Similar to research conducted by (Retariandalas, 2017) about the effect of reading interest and learning motivation on students' science learning achievement. He found that 1) there was a significant influence on Reading Interest and Learning Motivation on science learning achievement. This can be proven by the value of F-count $=13.038>\mathrm{F}$-table $=3.09$ and Sig $=0.000<0.05 ; 2$ ) There is no significant effect of reading interest on science learning achievement. This can be proven by the value of $\mathrm{t}=-0.289<\mathrm{t}$-table $=1.98$ and Sig $=0.773>0.05$.

These studies show that reading interest and student motivation must be balanced and must be done simultaneously to improve student learning achievement and motivation. It is very necessary to have motivation in learning activities because without motivation in learning it will not be possible for someone to carry out their learning activities (Prananda \& Hadiyanto, 2019). When students read subject matter at school or home during learning activities, of course, motivation is needed, a student who has high learning motivation will certainly affect the level of interest in reading the subject matter at school. (Supomo, 2019). The difference between the previous research and the research conducted lies in the dependent variable. In previous research, the measured dependent variable was limited to writing descriptive text skills, Indonesian language competency learning achievement, and science learning achievement. Meanwhile, in recent research. Therefore it is necessary to conduct further research to obtain data on the conditions of reading interest and student motivation towards science learning outcomes. So a study entitled "The Relationship between Reading Interest and Learning Motivation with Science Learning Outcomes of Class V SD Students, which aims to determine the relationship between reading interest and learning motivation with science learning outcomes of grade V SD students.

\section{Methodology}

This research was an "ex-post-facto" research because the researcher did not manipulate the state of the existing variables and directly looks for the existence of the relationship and the level of the relationship between the variables. According to Kerlinger (Sukardi, 2012), Ex-post facto research is a study in which the independent variables have occurred because the researcher begins by observing the dependent variable in a study. The subjects of this study were students of grade V SD. The population of this study was 187 students. From this population, it was taken based on the sample using the Warwick formula (Agung, 2014), and the sample in this study was 144 students. The sampling technique used is a proportional random sampling technique. Sampling considers the balance of $77 \%$ X $23=17.7=18$ people. The method of collecting data on student learning outcomes was obtained through the method of recording documents and to collect reading interest and learning motivation was obtained through a questionnaire. The reading interest questionnaire was developed according to (Dalman, 2014; Sudarsana, 2014) with the indicators of the reading interest questionnaire, namely reading pleasure, awareness of the benefits of reading, reading frequency, and reading quantity. The pleasure of reading is the tendency for someone to pay more attention and like something to certain activities without any coercion from other parties to read. The awareness of the benefits of reading is that students are aware that reading activities help the educational process. Reading frequency is how the frequency (frequency) and time a person uses to read, someone who has an interest in reading often does reading activities, and vice versa. Reading quantity is a person who has an interest in reading trying to read various readings. Students do not only read what students think is important.

The learning motivation questionnaire was developed according to (Uno, 2008; Sadirman, 2011) indicators of learning motivation, namely the desire and desire to succeed, the existence of encouragement and need in learning, the existence of hopes and aspirations for the future, the existence of appreciation in learning, the existence of interesting activities in learning, the existence of a conducive environment. The questionnaire on reading interest and learning motivation was tested first at school, then analyzed whether it was valid and reliable using the SPSS 17.0 For Windows program. Furthermore, 
the research was conducted by providing a questionnaire on reading interest and learning motivation in the study sample. The results of the study were analyzed using descriptive statistical tests, prerequisite analysis, and hypothesis testing. Descriptive statistics at the working level include ways of compiling, collecting, processing, organizing, presenting, and analyzing numerical data, to present a concise, regular, and clear picture of events, symptoms, or conditions (Sholikhah, 2016). The descriptive statistical test in this study is to determine the characteristics of the data in the form of mean, median, mode, standard deviation, and variance. After that, the hypothesis test data were analyzed using simple regression test and multiple regression, which is the correlation between two or more variables, namely the dependent variable together with the independent variable to find out how much the contribution of the correlation to the dependent variable (Rianto \& Neflilinda, 2018), calculation analysis using SPSS 17.0 For Windows program to find out whether the three variables have a relationship or not.

\section{Findings and Discussion}

The data from the research results have first described the characteristics of the data with descriptive statistical tests, then the prerequisites for regression analysis by testing the normality of the data, data linearity test, data multicollinearity test and heteroscedasticity test, and hypothesis testing with simple regression analysis followed by multiple regression analysis assisted by the SPSS program. version 17.0 for windows. The results of descriptive data analysis can be seen in table 1.

Table 1. Descriptive Statistics Test Results

\begin{tabular}{cccc}
\hline $\begin{array}{c}\text { Descriptive } \\
\text { Statistics Test }\end{array}$ & Reading Interest (X1) & $\begin{array}{c}\text { Learning Motivation } \\
\text { (X2) }\end{array}$ & $\begin{array}{c}\text { Science Learning } \\
\text { Outcomes (Y) }\end{array}$ \\
\hline Mean & 64 & 63 & 64 \\
Median & 65 & 63 & 65 \\
Standard Deviation & 21 & 21.50 & 20.40 \\
Variants & 437.00 & 462.00 & 416.00 \\
\hline
\end{tabular}

Table 1 explains the descriptive statistical test results of the independent variable and the dependent variable as follows: independent variable (X1) interest in reading obtained mean $=64$, median $=65$, standard deviation $=21$, and variance $=437.00$, independent variable $(\mathrm{X} 2)$ learning motivation obtained mean $=63$, median $=63$, standard deviation $=21.50$, variance $=462.00$, and the dependent variable $(\mathrm{Y})$ obtained mean $=64$, median $=65$, standard deviation $=20.40$, and variance $=416.00$. After obtaining the descriptive statistical test results, it was continued with the analysis of prerequisite tests in the form of normality test, linearity, autocorrelation test, multicollinearity test, and heteroscedasticity test. The results of the data normality test for the independent variables and the dependent variable can be seen in Table 02 as follows: 
Table 2. Results of Data Normality Test for Independent and Bound Variables

\begin{tabular}{cccc}
\hline & \multicolumn{3}{c}{ Kolmogorov-Smirnov } \\
\cline { 2 - 4 } Variable & Statistic & Df & Sig \\
\hline$Y$ & 0,69 & 144 & 0,90 \\
$X_{1}$ & 0,66 & 144 & 0,200 \\
$X_{2}$ & 0,71 & 144 & 0,960 \\
\hline
\end{tabular}

In Table 2, the data normality test of science learning outcomes for fifth-grade elementary school students was analyzed using the Kolmogorov-Smirnov test, this test is used to determine the suitability between a certain series of theoretical distributions and the observed scores (Silalahi, Hidayat, Seleky, Appulembang, \& Soesanto, 2019) Normality test assisted by SPSS version 17.0 for windows, normality test using the Kolmogorov-Smirnov technique was used because the data in this study amounted to 120 $(n>50)$. Based on the results of the data distribution normality test above, the significance value in the Kolmogorov Smirnov column gets a price of 0.90 , this result shows that it is greater than the significance level of 0.05 so that the student's science learning result value is normal. The data normality test of the results of reading interest among fifth-grade students was analyzed using the Kolmogorov-Smirnov test assisted by SPSS version 17.0 for windows, the normality test with Kolmogorov-Smirnov was used because the data in this study amounted to $120(n>50)$. Based on the results of the data distribution normality test above, the significance value in the Kolmogorov Smirnov column gets a price of 0.200 , this result shows that it is greater than the significance level of 0.05 so that the reading interest score is declared normal. The normality test of the student's learning motivation in grade V SD was analyzed using the Kolmogorov-Smirnov test, the Kolmogorov-Smirnov normality test was used because the data in this study amounted to $120(n>50)$. Based on the results of the data distribution normality test above, the significance value in the Kolmogorov Smirnov column gets a price of 0.07 , this result shows that it is greater than the significance level of 0.05 so that the learning motivation score is declared normal. Furthermore, the reading interest data with science learning outcomes are tested for linearity, the linearity test results can be seen in Table 3.

Table 3. Reading Interest Linearity Test Results with Science Learning Outcomes

\begin{tabular}{ccc}
\hline & \multicolumn{2}{c}{ Sig. } \\
\cline { 2 - 3 } Variable & Linearity & Deviation from Linearity \\
\hline $\mathrm{X}_{1}$ & 0,000 & 0,236 \\
$\mathrm{Y}$ & & 0,299 \\
$\mathrm{X}_{2}$ & 0,000 & 0,29 \\
$\mathrm{Y}$ & & \\
\hline
\end{tabular}

In Table 3, this regression linearity test is used for the linear regression model, the linearity test has the aim of knowing whether two variables have a linear relationship or have no significant correlation (Amirudin \& Andriana, 2016) so that the linearity test was carried out to determine the form of the relationship between each independent variable reading interest (X1) with the dependent variable on science learning outcomes (Y). Based on the analysis that has been done, it was found that the Linearity significance was $0.000(\mathrm{p}<0.05)$ so that the science learning outcomes of students with reading interest had a linear relationship, while the significance of Deviation from Linearity was 0.236 ( $>>0.05$ ) so that the science learning outcomes of students with reading interest had a significant relationship. In the linearity test of learning motivation (X2) with the dependent variable of science learning outcomes (Y), it was found that the Linearity significance was $0.000(p<0.05)$ so that students' science learning outcomes and learning motivation had a linear relationship. Meanwhile, the significance of Deviation from Linearity was 0.299 ( $>>0.05$ ) so that students' science learning outcomes and learning motivation had a significant relationship. Furthermore, the multicollinearity test of reading interest with learning motivation can be seen in Table 4. 
Table 4. Multicollinearity Test Results of Learning Motivation with Science Learning Outcomes

\begin{tabular}{ccccc}
\hline \multirow{2}{*}{ Variable } & \multicolumn{2}{c}{ Unstandardized } & \multicolumn{2}{c}{ Collinearity Coefficients } \\
\cline { 2 - 5 } & B & Std. & Tolerance & VIF \\
& 0.902 & 0,022 & 0.315 & 3.179 \\
$\mathrm{X}_{1}$ & 0.44 & 0,022 & 0.315 & 3.179 \\
$\mathrm{X}_{2}$ & &
\end{tabular}

In Table 3, the multicollinearity test is intended to find out whether there is a high enough relationship between the free variables of reading interest (X1) and learning motivation (X2), a condition that must be met in a multiple linear regression model when there is multicollinearity. (Kusuma, dan Wibowo, 2017). If there is a high correlation, it means that there are the same aspects measured in the independent variable. It is not appropriate to be used to determine the joint contribution of independent variables to the dependent variable. Based on the multicollinearity test, it is known that the reading interest data shows the beta coefficient value of 0.902 and the learning motivation data obtained by the beta coefficient value of 0.044 . While the standard error value of reading interest is 0.022 and learning motivation is obtained a standard error of 0.022 . From the results of the two beta coefficients and the standard error of less than (1.00), it can be stated that multicollinearity does not occur and the VIF (variance inflation factor) value and tolerance value shows that reading interest results in a VIF value of 3.179 less than 10.00 and a tolerance value of 0.315 more than 0.01 . It can be stated that the reading interest data does not occur multicollinearity, while the VIF value of student learning motivation is 3.179 less than 10.00 and a tolerance value of 0.315 is less than 0.01 , it can be stated that the student learning motivation data does not occur multicollinearity. Furthermore, the autocorrelation test can be seen in Table 5.

Table 5. Auto Correlation Test Results

\begin{tabular}{ccc}
\hline Variable & R & Durbin-Watson \\
\hline $\mathrm{X}_{1}$ & & \\
$\mathrm{X}_{2}$ & 0,988 & 1,847 \\
$\mathrm{Y}$ & & \\
\hline
\end{tabular}

In Table 4, autocoleration testing aims to be able to find out in the linear regression model within a certain time whether there is a correlation between sample members (Susanto, 2014) With the help of SPSS 17 for windows, it can be analyzed using the Durbin-Watson technique, that is, if the Durbin-Watson statistical value (d) is less than 4 minus the lower limit of Durbin-Watson (4-dL), it can be stated that autocorrelation occurs. Meanwhile, if the upper limit of Durbin-Watson (dU) is smaller than the DurbinWatson result and less than 4 minus the upper limit of Durbin-Watson (4-dU), it can be stated that there is no autocorrelation. Based on the test results, it was found that the Durbin-Watson value $=1,847$, with the Durbin-Watson upper limit being 1.7552 and 4 less the Durbin-Watson upper limit obtained 2.153. This result means that the Durbin-Watson upper limit statistical value is smaller than the Durbin-Watson statistical value, and is greater than 4 minus the upper limit value, namely $1.7552<1.847<2.153$, so that the data on reading interest and learning motivation with science learning outcomes does not occur autocorrelation. After the data is tested for the prerequisites, it is followed by a hypothesis test in the form of regression test analysis (Koyan, 2012) states that a regression test is a form of a functional relationship between predictor respondent variables. The point of regression is to predict. In this case, simple linear regression $\mathrm{Y}$ over $\mathrm{X}$. The $\mathrm{X}$ variable is the predictor variable (free, independent), while the $\mathrm{Y}$ variable is the criterion variable (response, dependent, dependent, dependent). In looking for a simple linear regression equation using $t$ is calculated with the help of SPSS version 17.0 for windows. The simple regression test results for reading interest and science learning outcomes can be seen in Table 6.

Table 6. Hypothesis Test Results in the Form of Regression of Reading Interest and Learning Motivation with Science Learning Outcomes

\begin{tabular}{ccc}
\hline Variable & $\mathbf{R}$ & R square \\
\hline $\mathrm{X}_{1}$ & 0,832 & 0,693 \\
$\mathrm{Y}$ & & 0,976 \\
$\mathrm{X}_{2}$ & 0,988 & 0,98
\end{tabular}




\begin{tabular}{ccc}
\hline Variable & R & R square \\
\hline$Y$ & 0,988 & 0,977 \\
$X_{1}$ & & \\
$X_{2}$ & 0,832 & 0,693 \\
\hline$Y$ & &
\end{tabular}

From Table 6, it is known that the $\mathrm{R}$ (correlation) value is 0.832 , while the $\mathrm{R}$ Square 0.693 value means that the contribution of reading interest (X1) to learning outcomes $(\mathrm{Y})$ is $69.3 \%$ while $30.7 \%$ of science learning outcomes are influenced by other variables. The amount of $r$ count can also show the significance of the correlation, the amount of $\mathrm{r}$ calculated in the results of data analysis is 0.832 , while the $\mathrm{r}$ table is obtained utilizing $\mathrm{df}=\mathrm{n}-2, \mathrm{df}=144-2=142$ is 0.138 , so $\mathrm{r}$ count is $0.832>\mathrm{r}$ table 0.138 , it can be stated that there is a significant relationship between reading interest and science learning outcomes. Furthermore, the X2 and Y values get an R-value (correlation of) 0.988 , the R Square value of $97.6 \%$ this value means that the contribution of learning motivation (X2) to learning outcomes (Y) is $97.6 \%$ while $2.4 \%$ of science learning outcomes are influenced by variables another. The amount of $r$ count can also show the significance of the correlation, the amount of $r$ count in the results of data analysis is 0.988 while the $\mathrm{r}$ table is obtained utilizing $\mathrm{df}=\mathrm{n}-2, \mathrm{df}=144-2=142$ is 0.138 , so $r$ count is $0.988>\mathrm{r}$ table 0.138 , it can be stated that there is a significant relationship between learning motivation and science learning outcomes. In Table 05, the joint correlation between reading interest and learning motivation with students' science learning outcomes is 0.988 , while the contribution of reading interest and learning motivation with science learning outcomes is $97.7 \%$, while $2.3 \%$ is influenced by other variables. The amount of $r$ count can also show the significance of the correlation, the amount of $r$ count in the results of data analysis is 0.988 , while the $r$ table is obtained utilizing $\mathrm{df}=\mathrm{n}-3, \mathrm{df}=144-3=141$ is 0.164 , so $\mathrm{r}$ count is $0.988>\mathrm{r}$ table 0.164 it can be stated that there is a significant relationship between reading interest and learning motivation with the science learning outcomes of grade V elementary school students.

\section{Relationship between Reading Interests and Science Learning Outcomes}

There is a significant relationship between reading interest and science learning outcomes. This is because reading interest is a constant tendency to pay attention to and enjoy several activities such as reading, reading itself has a very important social role in human life throughout the ages. Because reading is a way or an effort to seek knowledge as much as possible, besides that it is also a means of communication in a cultured society, the more knowledge you get, the more it can affect learning outcomes (Anwar, 2013). This is also to be able to develop a variety of knowledge which includes understanding concepts and in-depth scientific work on the surrounding nature, in addition to being sourced directly from nature, it can also be sourced from literature with reading activities, reading activities in science learning are useful so that students can understand conceptually about Science learning requires a strong interest in reading activities. Every individual always experiences a learning process in his life; learning will allow individuals to make changes in themselves. These changes can be in the form of mastery of a certain skill, change in attitude, having knowledge that is different from before someone did the learning process (Mulyani, 2013). By having an interest in reading, it will make it easier for students to understand the concepts and theories in science learning in order to provide initial knowledge and can more quickly help students understand the symptoms in nature. In accordance with the research results, it is known that there is a significant relationship between reading interest and science learning outcomes $(r=0.832)$. Based on the results of research conducted on the results of the reading interest questionnaire which has a high value, namely the intensity of reading, therefore the higher the reading intensity will affect student learning outcomes. In addition, reading interest has a relationship with science learning outcomes because it is for understanding science learning (Sofyan, 2019) argues that science at the primary school level will contribute to the whole process of children's education and further individual development. Science provides knowledge about the natural environment, develops skills, insights as an important means for mastery of science and technology as well as inculcating values and attitudes in respecting nature concerning human life, so that it has technological awareness concerning the use of everyday life, besides learning science directly through scientific activities that come from nature, students can understand science conceptually with reading activities, which are supported by (Sahrudin, 2013) that to conceptually understand science learning, it is necessary to have a strong desire or a strong interest in reading this to improve learning achievement.

The results of this study are also supported by the results of research which show that reading interest and learning outcomes have a significant relationship (Mariskhana, 2019), The researcher explained that students who have a desire to read will have broad insights because they always get new things from what they read. The way to increase students' reading interest in science learning materials, 
must have a high awareness of the importance of reading and must be accustomed to taking the time to read. Aspects of family, society, and educational institutions have an important role in increasing people's interest in reading. These three aspects need to be done simultaneously. Teachers and librarians play an important role in increasing the reading interest of students and society. To play a role in increasing reading interest, teachers and librarians must have a high interest in reading. Therefore, the exemplary needs to be given to society. If teachers and librarians do not have a high reading interest, it is impossible to carry out their duties in increasing reading interest (Kasiyun, 2015). Therefore, students' reading interest is thought to be a factor that influences science learning outcomes and improves science learning outcomes. The higher the students' reading interest, the higher the likelihood of obtaining good science learning outcomes. Thus, to obtain optimal science learning outcomes, students need to increase their reading interest.

\section{The Relationship between Learning Motivation and Science Learning Outcomes}

Learning is a process of changing behavior as a result of the interaction of himself and his environment to achieve the needs of life, with the learning motivation that students have in each learning activity provides a role in being able to improve learning outcomes, learning motivation is a conscious effort to drive and maintain behavior. someone so that he is motivated to act to do something to achieve a certain result or goal (Sappe \& Ernawati, 2018). Motivation is a conscious effort to move, direct, and maintain a person's behavior so that he is motivated to act to do something to achieve certain results or goals. One of the factors that affect student achievement is motivation. With motivation, students will study harder, be resilient, diligent, and have and have full concentration in the learning process. Motivation encouragement in learning is one thing that needs to be raised in the learning process (Ghullam, 2011). Science learning outcomes are also strongly influenced by student motivation (Pratama et al., 2019). In line with that, motivation is needed in learning activities because without motivation in learning it will not be possible for someone to do their learning activities (Prananda \& Hadiyanto, 2019)

In line with the results of the research that has been done, there is a significant relationship between learning motivation and science learning outcomes $(r=0.988)$. Based on the results of research conducted on the results of the indicator motivation questionnaire which has the highest value, namely the encouragement and need in learning, therefore with learning motivation in the form of encouragement and meeting the needs of students in learning it can affect students learning outcomes. In addition, the results of this study are supported by statements; that motivation to learn is a conscious effort to move someone's behavior to direct and maintain one's behavior so that he is motivated to act to do something to achieve certain results or goals (Sappe \& Ernawa, 2018). Therefore, the results of science learning are strongly influenced by student motivation (Pratama \& Firman, 2019), and motivation is needed in learning activities because without motivation in learning it will not be possible for someone to do their learning activities (Prananda \& Hadiyanto, 2019). The results of this study are also supported by the research conducted by (Sahrudin, 2013) which states that there is a significant relationship between learning motivation and learning achievement. In addition, research from (Retariandalas, 2017) also states that there is a significant influence of learning motivation on science learning achievement. This can be proven by the value of $t=4.089>t$-table $=1.98$ and Sig. $=0.000<0.05$. Motivation to learn influences student achievement, namely encouraging, increasing enthusiasm and persistence in the pleasure of learning economics so that students are highly motivated and have a lot of energy to carry out the science learning process. Motivation to learn is a good encouragement from themselves and from outside of students who are learning to make changes in behavior. Related to this research, learning motivation influences the learning outcomes it gets. In the science learning process, motivation is needed because people who do not have the motivation to learn, it is impossible to carry out learning activities, this concerns the needs of students in learning. Thus, learning motivation is one of the factors to improve optimal learning outcomes. Students who have high learning motivation tend to influence student learning outcomes.

\section{The Relationship between Reading Interest and Learning Motivation with Science Learning Outcomes}

Science subjects are subjects that teach about the natural surroundings and the environment through scientific activities, efforts to achieve basic competencies in science subjects in elementary schools, creativity, student skills are needed to be able to achieve optimal learning outcomes in the form of solving problems related to Science in everyday life and mastery of concepts (Silviana, 2018). Therefore, to understand science learning, reading activities are needed. One of the main factors for achieving success in any field, whether it be studying, work, hobbies, or any activity is interest. With the growing interest in a person, it will generate attention to do something diligently for a long time, more 
concentration, easy to remember, and not easily bored with what is being learned (Sirait, 2016). In addition, interest in reading occupies an important place because it is one of the driving factors for someone to do and increase reading activities and is the main source of reading activities (Putri, 2011). Furthermore, in addition to reading interest, another factor in students itself that causes an influence on learning outcomes is learning motivation (Sari, 2018). Thus, the intensity of reading interest and high learning motivation will affect student learning outcomes. One's success in the learning process depends on oneself and also from the environment. A strong desire from within oneself to succeed will make a person more active in studying. Success in learning is also influenced by the facilities owned by the school. Complete and adequate facilities will make students enthusiastic about learning and easy to understand learning materials so they can get good grades. Facilities that are lacking or even non-existent will also harm student learning outcomes. Students with aspirations and aspirations to learn, indirectly get the motivation to learn so that they can achieve what they aspire to. Good situations and conditions can also be encouraging in learning. On the contrary, if the student is not in a good/sick condition, then the student will not have enthusiasm for learning (Palittin, 2019).

In accordance with the results of research that has been conducted, it is known that there is a significant relationship between reading interest and learning motivation with science learning outcomes $(r=0.998)$. This proves that some of the factors that can affect student science learning outcomes are reading interest and student learning motivation contained in the questionnaire data for reading interest indicators that have high values, namely reading intensity, therefore the higher the reading intensity will affect student learning outcomes. and the results of the indicator motivation questionnaire that has the highest value, namely the encouragement and need in learning, therefore, with learning motivation in the form of encouragement and meeting the needs of students in learning it can affect student learning outcomes. This research was also supported by research that conducted reading interest and learning motivation had a significant effect on the grade XI IPA student achievement index (Supomo, 2019). Furthermore, other studies that describe a significant correlation between reading interest and learning motivation with learning outcomes (Rahayu, 2016), and there is a significant relationship between reading interest and learning motivation with science learning achievement (Retariandalas, 2017). Thus, reading interest and learning motivation are factors that affect students' science learning outcomes, the higher the students' reading interest and learning motivation, thereby increasing students' science learning outcomes.

\section{Conclusion}

Based on the results of research and discussion, it can be concluded that first, there is a significant relationship between reading interest and science learning outcomes, this relationship shows that if students' reading interest is high, then student learning outcomes tend to be high. Second, there is a significant relationship between learning motivation and science learning outcomes of grade V SD students. This relationship shows that if student learning motivation is high, then student learning outcomes tend to be high. Third, there is a significant relationship between reading interest and learning motivation with the science learning outcomes of grade V SD students. This relationship shows that if reading interest and student learning motivation are high, then student learning outcomes tend to be high.

\section{References}

Agung, A. A. G. (2014). Buku Ajar Metodologi Penelitian Pendidikan. Yogyakarta: Aditya Media Publishing.

Alannasir, W. (2016). Pengaruh penggunaan media animasi dalam pembelajaran IPS terhadap motivasi belajar siswa kelas IV SD Negeri Mannuruki. Journal of Educational Science and Technology (EST), 2(2), 81-90. https://doi.org/10.26858/est.v2i2.2561

Amirudin, T., \& Andriana, D. (2016). Pengaruh Likuditas Dan Nilai Tukar Terhadap Harga Saham Setelah Ipo Pada Perusahaan Yang Terdaftar Di Bursa Efek Indonesia Tahun 2009. Jurnal Riset Akuntansi Dan Keuangan Universitas Pendidikan Indonesia, 4(1), 952. https://doi.org/10.17509/jrak.v4i1.7718

ANWAR, K. Hubungan Antara Kemampuan Membaca Dengan Hasil Belajar Mata Kuliah Ipa Kelas Tinggi Mahasiswa Pgsd Transfer D-Ii Ta 2013/2014. Jurnal Handayani Pgsd Fip Unimed,1(1). https://doi.org/10.24114/jh.v1i1.1249

Dalman. (2014). Keterampilan Membaca. Jakarta: PT. Rineka Cipta. 
Emelinda, Benge. 2017. Hubungan Antara Minat Dan Motivasi Belajar Dengan Hasil Belajar IPA Pada Siswa SD. Journal of Education Technology, Vol. 1(4);(231- 238). http://dx.doi.org/10.23887/jet.v1i4.12859

Fitriyani, E., \& Pramusinto, H. (2018). Pengaruh Fasilitas Perpustakaan, Kualitas Pelayanan, dan Kinerja Pustakawan Terhadap Minat Berkunjung Masyarakat. Economic Education Analysis Journal, 7(2), 585-595. https://journal.unnes.ac.id/sju/index.php/eeaj/article/view/28277

Hamdu, G., \& Agustina, L. (2011). Pengaruh motivasi belajar siswa terhadap prestasi belajar IPA di sekolah dasar. Jurnal penelitian pendidikan,12(1), http://www.academia.edu/download/35968572/8-Ghullam_Hamdu1.pdf.

Kasiyun, S. (2015). Upaya meningkatkan minat baca sebagai sarana untuk mencerdaskan bangsa. Jurnal Pena Indonesia, 1(1), 79-95. http://dx.doi.org/10.26740/jpi.v1n1.p79-95

Koyan, I. W. (2012). Statistik Pendidikan "Teknik Analisis Data Kuantitatif". Singaraja: Universitas Pendidikan Ganesha.

Laksana, D.N L. (2017). The Effectiveness of Inquiry-Based Learning for Natural Science Learning in Elementary School. Journal of Education Technology, Vo. 1(1); (1-5). http://dx.doi.org/10.23887/jet.v1i1.10077

Lawe, Y. U. (2018). Pengaruh Model Pembelajaran Berbasis Proyek Berbantuan Lembar Kerja Siswa Terhadap Hasil Belajar IPA Siswa SD. Journal of Education Technology, 2(1), 26-34. http://dx.doi.org/10.23887/jet.v2i1.13803

Maola, Minkahtul, dkk. 2019. Hubungan Minat Baca Dengan Prestasi Belajar Kompetensi Bahasa Indonesia Siswa Kelas IV SD. Prodising Konferensi Ilmiah Mahasiswa Unissula (KIMU) 2 Universitas Islam Sultan Agung, ISSN. http://jurnal.unissula.ac.id/index.php/kimuhum/article/view/8269

$2720-9148$.

Mariskhana, K. (2019). Prestasi Belajar Sebagai Dampak Dari Minat Baca Dan Bimbingan Belajar Siswa IPS. Cakrawala, 19(1), 77. https://doi.org/10.31294/jc.v19i1.4454

Mulyani, D. (2013). Hubungan kesiapan belajar siswa dengan prestasi belajar. Konselor, 2(1).

Mumpuni, Atikah \& Rizki Umi Nurbaeti. 2019. Analisa Faktor yang Mempengaruhi Minat Baca Mahasiswa PGSD. DWIJA CENDIKIA: Jurnal Riset Pedagogik, Vol 3(2);(123-132). https://doi.org/10.20961/jdc.v3i2.35229

Oktarilla, Annisa, dkk. 2019. Kontribusi Minat Baca Dan Motivasi Belajar Terhadap Keterampilan Menulis Teks Deskripsi Siswa Kelas VII SMP Negeri 7 Padang. Jurnal Pendidikan Bahasa dan Sastra Indonesia, Vol.8(3);(8-14). https://e-jurnal.stkiprokania.ac.id/index.php/jpr/article/view/36

Palittin, I. D., Wolo, W., \& Purwanty, R. (2019). Hubungan motivasi belajar dengan hasil belajar siswa. Magistra: Jurnal Keguruan dan Ilmu Pendidikan, 6(2), 101-109. http://ejournal.unmus.ac.id/index.php/magistra/article/view/1801

Permatasari, A. (2015). Membangun Kualitas Bangsa Dengan Budaya Literasi. Prosiding Seminar Nasional Bulan Bahasa.

Prananda \& Hadiyanto. (2019). Korelasi Antara Motivasi Belajar Dengan Hasil Belajar Siswa Dalam Pembelajaran IPA di Sekolah Dasar. Jurnal Basicedu, 3(3), 911. https://doi.org/10.31004/basicedu.v3i3.181

Pratama, Firman, N. (2019). Pengaruh Motivasi Belajar IPA Siswa Terhadap Hasil BelajarDi Sekolah Dasar Negeri 01. Edukatif: Jurnal Ilmu Pendidikan, 1(3), 281. https://doi.org/10.31004/edukatif.v1i3.63

Putri, M. (2011). Kontribusi Minat Baca Dan Membaca Pemahaman Terhadap Keterampilan Menulis Argumentatif Siswa Kelas X Sma Semen Padang. Lingua Didaktika: Jurnal Bahasa dan Pembelajaran Bahasa, 5(1), 52-63. https://doi.org/10.24036/ld.v5i1.9974

Rahayu, I. (2016). Hubungan Minat Membaca dan Motivasi Belajar Dengan Hasil Belajar Materi Menulis Karangan Pada Warga Belajar Kejar Paket C Di PKMB Al-Firdaus Kabupaten Serang. Jurnal Untirta, 1(2), 199. http://dx.doi.org/10.30870/e-plus.v1i2.1165

Retariandalas. (2017). Pengaruh Minat Membaca dan Motivasi Belajar Terhadap Prestasi Belajar IPA Siswa. Jurnal Formatif, 7(2), 196. http://dx.doi.org/10.30998/formatif.v7i2.1529 
Rianto dan Neflilinda. (2018). Faktor Yang Mempengaruhi Sanitasi Lingkungan Permukiman Di Nagari AUR Begalung Kecamatan Bayang Kabupaten Pesisir Selatan. Jurnal Penelitian, Terapan Ilmu Geografi, Dan Pendidikan Geografi, 5(2), 66. https://doi.org/10.22202/js.v5i2.3091

Sadirman. (2011). Interaksi dan Motivasi Belajar Mengajar. Jakarta: PT. Raja Grafindo Persada.

Safitri, L., \& Muslim, A. H. (2019). Jurnal cakrawala pendas. 5(2), 153-157.

Sappe, Ernawati, I. (2018). Hubungan Motivasi Belajar Terhadap Hasil Belajar IPA Siswa Kelas V SDN 231 aten Takalar. Jurnal Kajian Pendidikan Dasar, 3(2), 351. https://doi.org/10.26618/jkpd.v3i2.1419

Sari, A. (2018). Pengaruh Minat Baca dan Motivasi Belajar terhadap Hasil Belajar Siswa Kelas XI IIS Pada Mata Pelajaran Ekonomi di SMA Negeri 1 Mojosari. Jurnal Pendidikan Ekonomi (JUPE), 6(3) https://doi.org/10.26740/jupe.v6n3.p\%25p

Shofaussamawati. (2014). Menumbuhkan Minat Baca dengan Pengenalan Perpustakaan Pada Anak Sejak Dini. Libraria, 2(1), 46-49. http://dx.doi.org/10.21043/libraria.v2i1.1189

Sholikhah, A. (2016). Statistika Deskriptif Dalam Penelitian Kualitatif. Komunika, 10(2), 345. http://ejournal.iainpurwokerto.ac.id/index.php/komunika/article/view/953

Silalahi, D. K., Hidayat, D., Seleky, J. S., Appulembang, O. D., \& Soesanto, R. H. (2019). Pengaruh Pembelajaran Responsi Pada Mata Kuliah Kalkulus II Terhadap Hasil Belajar Mahasiswa Program Studi Pendidikan Matematika FIP UPH. Jurnal Edumat Sains, 3(2), 173. https://doi.org/10.33541/edumatsains.v3i2.887

Silviana, A. M. G. (2018). Penggunaan Model Inkuiri Pendekatan Eksperimental Untuk Meningkatkan Penguasaan Siswa Terhadap Sifat-sifat Cahaya. Jurnal Ilmiah Pendidikan Guru Sekolah Dasar, 5(1), 2. https://ejournal.upi.edu/index.php/pedadidaktika/article/view/7144

Sirait, E. D. (2016). Pengaruh minat belajar terhadap prestasi Belajar Matematika. Formatif: Jurnal Ilmiah Pendidikan MIPA, 6(1). http://dx.doi.org/10.30998/formatif.v6i1.750

Sudarsana, U. (2014). Pembinaan Minat Baca. Banten: Universitas Terbuka.

Sukardi. (2012). Metodologi Penelitian Pendidikan. Jakarta: PT. Bumi Aksara.

Supomo. (2019). Minat Membaca dan Motivasi Belajar Dalam Meningkatkan Indeks Prestasi. Jurnal Ilmu Pendidikan Indonesia, 7(1), 43. https://doi.org/10.31957/jipi.v7i1.840

Susanti, V. D. (2014). Efektivitas Model Pembelajaran Portofolio Dan Model Pembelajaran Kooperatif Think Pair And Share (Tps) Terhadap Prestasi Belajar Matematika Ditinjau Dari Kreativitas Siswa Vii Smp Negeri 2 Kebonsari Tahun Ajaran 2011/2012. JIPM Jurnal Ilmiah Pendidikan Matematika), 2(2), 32-36. https://doi.org/10.31957/jipi.v7i1.840

Susanto, S. (2014). Pengaruh Budaya Perusahaan Dan Motivasi Kerja Terhadap Kepuasan Kerja Karyawan Bambang. Jurnal Studia Akuntansi Dan Bisnis Universitas Negeri Jakarta, 1(3), 329. https://ejurnal.latansamashiro.ac.id/index.php/JSAB/article/view/34

Syofyan, H., Zulela, M. S., \& Sumantri, M. S. (2019). Pengembangan Awal Bahan Ajar IPA Di Sekolah Dasar. Jurnal http://journal.unj.ac.id/unj/index.php/jpd/article/view/11266

Dasar, 10(1), 52-67.

Triatma. (2016). Minat Baca Pada Siswa Kelas VI Sekolah Dasar Negeri Delegan 2 Prambanan Sleman Yogyakarta. E-Jurnal Prodi Teknologi Pendidikan, 5(6), 166-178. http://journal.student.uny.ac.id/ojs/index.php/fiptp/article/view/3098

Uno, H. (2008). Teori Motivasi \& Pengukuran. Jakarta: PT. Bumi Aksara.

Widani, N. K. T., Sudana, D. N., \& Agustiana, I. G. A. T. (2019). Pengaruh Model Pembelajaran Inkuiri Terbimbing Terhadap Hasil Belajar Ipa Dan Sikap Ilmiah Pada Siswa Kelas V Sd Gugus I Kecamatan Nusa Penida. Journal of Education Technology, 3(1), 15-21. http://dx.doi.org/10.23887/jet.v3i1.17959 